\title{
Determination of Propagation Rate Coefficient of Free-Radical Polymerization of $N$-Vinylcarbazole by Pulsed-Laser Polymerization
}

\author{
Masataka Онока, Sadahito Misumi, and Masahide Yамамото \\ Department of Polymer Chemistry, Graduate School of Engineering, \\ Kyoto University, Kyoto 606-8501 Japan \\ (Received March 25, 1999)
}

\begin{abstract}
Pulsed-laser polymerization in conjunction with molecular weight distribution measurement was adopted for determining the propagation rate coefficient $k_{\mathrm{p}}$ in the free radical solution polymerization of $N$-vinylcarbazole (VCZ). A photoinitiator which absorbs up to $c a .410 \mathrm{~nm}$ was selected to exclude the excitation of VCZ. We measured the effects of light intensity, pulse frequency and the concentration of $\mathrm{VCZ}$ on the rate coefficients. The value $k_{\mathrm{p}}=4.16 \times 10^{3} \mathrm{~L} \mathrm{~mol}^{-1} \mathrm{~s}^{-1}$ was obtained in benzene at $30^{\circ} \mathrm{C}$. The values of $k_{\mathrm{p}}$ were well fitted by the Arrhenius equation in the range of $30-70^{\circ} \mathrm{C}$. The values evaluated by using the non-linear least-squares fitting for determination of Arrhenius parameters were $A=2.20 \times 10^{8} \mathrm{~L} \mathrm{~mol}^{-1} \mathrm{~s}^{-1}$ and $E_{\mathrm{A}}=27.4 \mathrm{~kJ} \mathrm{~mol}^{-1}$. We obtained the $95 \%$ joint confidence interval for the Arrhenius parameters.

KEY WORDS N-Vinylcarbazole / Radical Polymerization / Propagation Rate Coefficient / Pulsed-Laser Polymerization /
\end{abstract}

The radical and cationic polymerization of $N$-vinylcarbazole (VCZ) has been extensively studied. ${ }^{1,2}$ In the polymerization kinetics, it is important to determine the propagation rate constant $k_{\mathrm{p}}$. North et $a l^{3}$ measured the propagation rate constant for radical polymerization of VCZ by using the rotating sector-dilatometry method and reported the value of $k_{\mathrm{p}}=13 \mathrm{~L} \mathrm{~mol}^{-1} \mathrm{~s}^{-1}$ in tetrahydrofuran (THF) at $30^{\circ} \mathrm{C}$, which is listed in the "Polymer Handbook". ${ }^{4}$ We have reported a much higher value of $k_{\mathrm{p}}=930 \mathrm{~L} \mathrm{~mol}^{-1} \mathrm{~s}^{-1}$ in benzene at $30^{\circ} \mathrm{C}$ by the same method. ${ }^{5}$ Recently, Olaj and coworkers ${ }^{6}$ developed the pulsed-laser polymerization (PLP) technique by which the propagation rate constant of radical polymerization can be evaluated accurately. In this technique the propagation rate constants can be estimated from the molecular weight distribution of the obtained polymer. The original concept was outlined by Aleksandrov. ${ }^{7}$ Many workers have determined the propagation rate constants for various different monomer systems, such as styrene, ${ }^{8-10}$ acrylate, ${ }^{11-13}$ methacrylate ${ }^{14-19}$ and vinyl acetate. ${ }^{20}$ These studies were carried out mostly using bulk polymerization and a few using solution polymerization..$^{21-23}$ In this study, the propagation rate constant of VCZ was measured in solution with an appropriate photoinitiator by the PLP technique. The absorption of VCZ has a long wavelength tail in the $\mathrm{UV}$ region, i.e., the absorption maximum is at $340 \mathrm{~nm}$ and the tail extends to $390 \mathrm{~nm}$ at a high monomer concentration, so we adopted the photoinitiator whose absorption band is in a longer wavelength than the absorption of VCZ.

\section{EXPERIMENTAL}

VCZ (Nakarai tesque) was purified by recrystallization three times from methanol and hexane. Then it was dried in vacuo for two days at room temperature. The solvent was purified by the usual way. In this study, we used 2-benzyl-2-dimethylamino-1-(4-morpholinophenyl)butanone-1 (Irgacure 369, Ciba Geigy) as a photoinitiator which has an absorption tail up to $c a$.
$410 \mathrm{~nm}$. Figure 1 shows the molecular structure of the initiator and monomer. The solution in the sample cell was bubbled with argon gas for $10 \mathrm{~min}$. Pulsed-laser experiments were performed by using a Lambda Physik EMG 101 MSC pulsed excimer laser at $351 \mathrm{~nm}(\mathrm{XeF})$ with a pulse energy of $60 \mathrm{~mJ}$. The pulse repetition rate could be changed from $1 \mathrm{~Hz}$ to $50 \mathrm{~Hz}$. The temperature was kept constant within $\pm 0.5^{\circ} \mathrm{C}$. After polymerization, the molecular weight distribution was analyzed at $40^{\circ} \mathrm{C}$ on a high speed liquid chromatography system HLC802UR (Tosoh Co. Ltd). A column (Tosoh, TSK-GEL, G4000 HHR $\times 2$ ) and a differential refractometer were used. THF was used as the eluent, and pumped at a constant flow of $0.8 \mathrm{~mL} \mathrm{~min}^{-1}$. The molecular weight distribution (MWD) analysis was based upon universal calibration by using narrow MWD polystyrene standards (Tosoh standard sample) and known Mark-Houwink-Sakurada coefficients. ${ }^{4,24}$ This calibration curve was checked with a few samples of narrow-MWD PVCZ that were prepared by living cationic polymerization ${ }^{25}$ and their $M_{w}$ 's were measured by LS.

\section{Procedure}

The PLP technique has been described in many papers $^{8,26}$ and has been recommended for use by the IUPAC working party. ${ }^{9,14}$ The technique involves the exposure of a monomer system with a photoinitiator to laser flashes which generate a periodic profile of polymer radicals. The photoinitiator decomposes during the laser
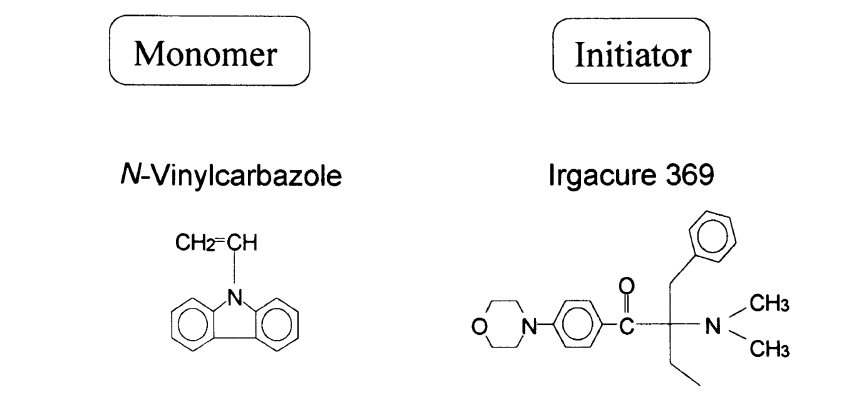

.

Figure 1. The molecular structure of monomer and photoinitiator. 


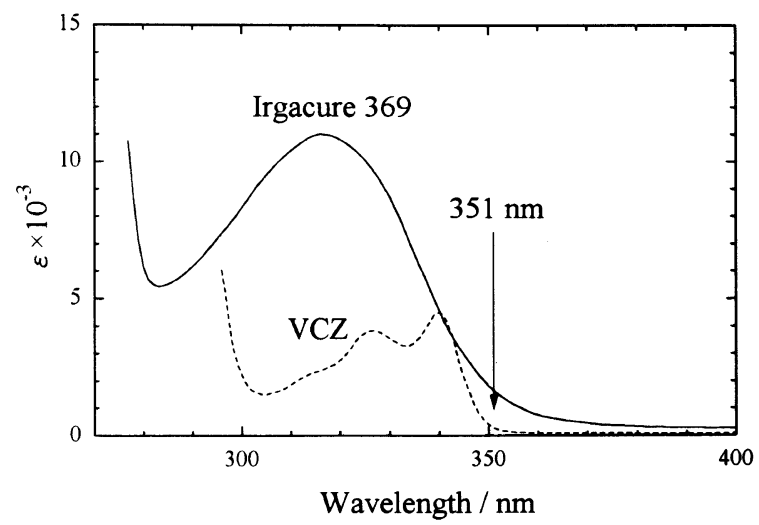

Figure 2. Absorption spectra of VCZ (broken line) and Irgacure 369 (full line).

pulse and the radical formed can initiate the propagation. When the next laser pulse arrives, the radical is exposed to a high concentration of newly generated radicals, which lead to their termination with a greatly increased probability. If a propagation radical is terminated by the $i$-th pulse after the initiating pulse, the chain length $L_{i}$ of the polymer formed is determined by the following equation.

$$
L_{i}=i k_{\mathrm{p}}[\mathrm{M}] t_{0}
$$

where $[\mathrm{M}]$ is the monomer concentration, $t_{0}$ is the dark time between pulses, and $i$ is an integer. The MWD of the sample which is obtained by irradiating a sequence of pulse light is measured by size exclusion chromatography (SEC). The MWD derived from SEC is obtained as $w(\log M) v s . \log M$, where the fraction of polymer $w$ is expressed as a function of $\log M$. To analyze the experimental data, it is necessary to transform a mass MWD on a logarithmic scale to a number MWD on a linear scale. The relation between $w(M)$ and $w(\log M)$ is given by,

$$
w(\log M)=\ln (10) M \times w(M)
$$

$f(M)$ is given by $w(M)$ as,

$$
f(M) \approx w(M) / M
$$

Then, by taking the derivatives of $w(\log M), w(M), f(M)$, the peaks of $\mathrm{d} w(\log M) / \mathrm{d} \log M, \mathrm{~d} w(M) / \mathrm{d} M$ and $\mathrm{d} f(M) /$ $\mathrm{d} M$ become the inflection points on the low molecular weight side on the major MWD peak which is $L_{i}$. As $L_{i}$ is determined, we can calculate $k_{\mathrm{p}}$ by using eq 1 . Towards higher $i$, the inflection point becomes vague and in most cases eq 1 is used with $i=1$

\section{RESULTS AND DISCUSSION}

Figure 2 shows the absorption spectra of $\mathrm{VCZ}$ $\left(1 \times 10^{-4} \mathrm{~mol} \mathrm{~L}^{-1}\right)$, Irgacure $369\left(1 \times 10^{-3} \mathrm{~mol} \mathrm{~L}^{-1}\right)$ in benzene solution. The photoinitiator Irgacure 369 has an absorption tail up to $c a .410 \mathrm{~nm}$. VCZ has absorption at the exciting laser pulse wavelength of $351 \mathrm{~nm}$, but the polymerization did not take place when the system was irradiated in the absence of Irgacure 369. The mechanism of photodecomposition of Irgacure 369 has been studied by Desobry et $a_{l}{ }^{27}$ The main initiating species of polymerization is benzoyl and aminoalkyl radicals.

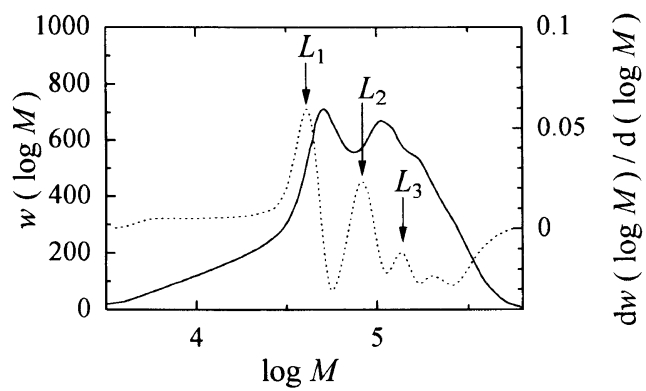

Figure 3. Molecular weight distribution $w(\log M)$ (full line) of the polymer formed in PLP experiment for $\mathrm{VCZ}$ [ temperature, $30^{\circ} \mathrm{C}$; $t_{0}=0.1 \mathrm{~s} ; \mathrm{VCZ}\left(0.5 \mathrm{~mol} \mathrm{~L}^{-1}\right)$; Irgacure $369\left(2 \times 10^{-3} \mathrm{~mol} \mathrm{~L}^{-1}\right)$; solvent, benzene] and the first derivative $\mathrm{d} w(\log M) / \mathrm{d}(\log M)$ (broken line) the inflection points are shown as $L_{i}$.

Table I. Inflection points and $k_{\mathrm{p}}$ estimates for $\mathrm{VCZ}^{\mathrm{a}}$

\begin{tabular}{lcccc}
\hline & & $w(\log M)$ & $w(M)$ & $f(M)$ \\
\hline \multirow{2}{*}{ First } & $L_{1}$ & 210 & 206 & 202 \\
& $k_{\mathrm{p}}\left(\mathrm{L} \mathrm{mol}^{-1} \mathrm{~s}^{-1}\right)$ & $4.20 \times 10^{3}$ & $4.12 \times 10^{3}$ & $4.04 \times 10^{3}$ \\
\multirow{2}{*}{ Second } & $L_{2}$ & 426 & 410 & 405 \\
& $k_{\mathrm{p}}\left(\mathrm{L} \mathrm{mol}^{-1} \mathrm{~s}^{-1}\right)$ & $4.26 \times 10^{3}$ & $4.10 \times 10^{3}$ & $4.05 \times 10^{3}$ \\
\hline
\end{tabular}

${ }^{a} \mathrm{VCZ}\left(0.5 \mathrm{~mol} \mathrm{~L}^{-1}\right)$; Irgacure $369\left(2 \times 10^{-3} \mathrm{~mol} \mathrm{~L}^{-1}\right)$; solvent, benzene; temperature, $30^{\circ} \mathrm{C}$; irradiation wavelength, $351 \mathrm{~nm}$; laser repetition rate, $10 \mathrm{~Hz}$.

Table II. Effect of laser light intensity in PLP experiment ${ }^{a}$

\begin{tabular}{cccc}
\hline Light intensity $/ \%$ & MW at $L_{1}$ & $L_{1}$ & $k_{\mathrm{p}} / \mathrm{L} \mathrm{mol}^{-1} \mathrm{~s}^{-1}$ \\
\hline 100 & $7.96 \times 10^{4}$ & 412 & $4.12 \times 10^{3}$ \\
40 & $8.39 \times 10^{4}$ & 434 & $4.34 \times 10^{3}$ \\
20 & $8.10 \times 10^{4}$ & 419 & $4.19 \times 10^{3}$ \\
\hline
\end{tabular}

${ }^{\mathrm{a}} \mathrm{VCZ}\left(0.5 \mathrm{~mol} \mathrm{~L}^{-1}\right) ;$ Irgacure $369\left(2 \times 10^{-3} \mathrm{~mol} \mathrm{~L}^{-1}\right)$; solvent, benzene; temperature, $30^{\circ} \mathrm{C}$; irradiation wavelength, $351 \mathrm{~nm}$; laser repetition rate, $5 \mathrm{~Hz}$.

Figure 3 shows the molecular weight distribution of the polymer formed on irradiating $10 \mathrm{~Hz}$ of $351 \mathrm{~nm}$ light at $30^{\circ} \mathrm{C}$ for $10 \mathrm{~min}$. Table I shows the chain length $L_{i}$ at the inflection points and the estimated $k_{\mathrm{p}}$. They are not greatly different but are in the order of $w(\log M) \geq$ $w(M) \geq f(M)$, which is the same as that reported by Hutchinson et al. ${ }^{8}$ Although they regard the value of $f(M)$ as valid, we adopt the $w(M)$ distribution for comparison with the reported values. As can be seen in Table I, the relation between the first peak and the second peak is $L_{2} \cong 2 \times L_{1}$.

As for light intensity, we changed the light intensity from $100 \%$ to $40 \%$ and from $40 \%$ to $20 \%$ under the same condition, but the SEC curves nearly overlapped each other and the $k_{\mathrm{p}}$ values were nearly the same. The results are summarized in Table II. Figure 4 shows the SEC curves obtained by changing the frequency from $5 \mathrm{~Hz}$ to $30 \mathrm{~Hz}$, i.e., $t_{0}$ was changed from $0.2 \mathrm{~s}$ to $0.033 \mathrm{~s}$. When $t_{0}$ was short, the system was at the low termination limit ${ }^{12}$ because the next pulse arrived before the radical had decayed fully. With the increase in $t_{0}$, the curve approached the higher polymer side and showed two distinct peaks. As $t_{0}$ reached 0.1 or $0.2 \mathrm{~s}$, the condition became appropriate for the PLP method. Therefore, the 


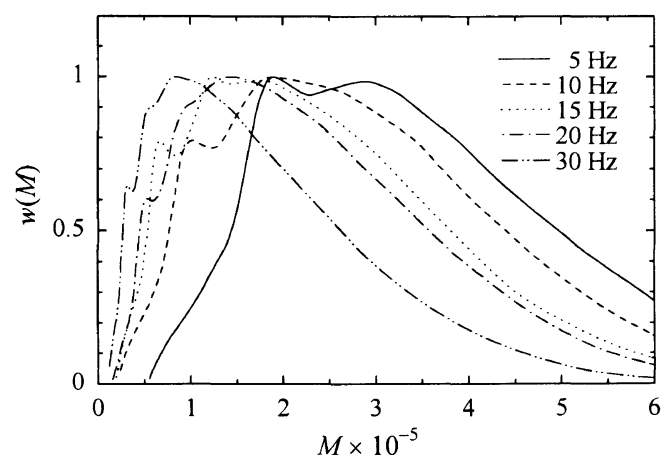

Figure 4. Dependence of molecular weight distribution of the polymer on the frequency of laser pulse in benzene at $30^{\circ} \mathrm{C}$.

Table III. Effect of frequency of laser pulse in PLP experiment ${ }^{\mathrm{a}}$

\begin{tabular}{lccccc}
\hline \multicolumn{1}{c}{ Frequency $/ \mathrm{Hz}$} & 5 & 10 & 15 & 20 & 30 \\
\hline$t_{\mathrm{o}} / \mathrm{s}$ & 0.2 & 0.1 & 0.067 & 0.05 & 0.033 \\
$\mathrm{MW}$ at $L_{1}\left(\times 10^{4}\right)$ & 16.2 & 7.96 & 5.25 & 4.25 & 2.67 \\
$L_{1}$ & 838 & 412 & 272 & 220 & 138 \\
$k_{\mathrm{p}}\left(\times 10^{3} \mathrm{~L} \mathrm{~mol}^{-1} \mathrm{~s}^{-1}\right)$ & 4.19 & 4.12 & 4.06 & 4.39 & 4.17 \\
\hline
\end{tabular}

${ }^{\mathrm{a}} \mathrm{VCZ}\left(1.0 \mathrm{~mol} \mathrm{~L}^{-1}\right)$; Irgacure $369\left(2 \times 10^{-3} \mathrm{~mol} \mathrm{~L}^{-1}\right)$; solvent, benzene; temperature, $30^{\circ} \mathrm{C}$; irradiation wavelength, $351 \mathrm{~nm}$.

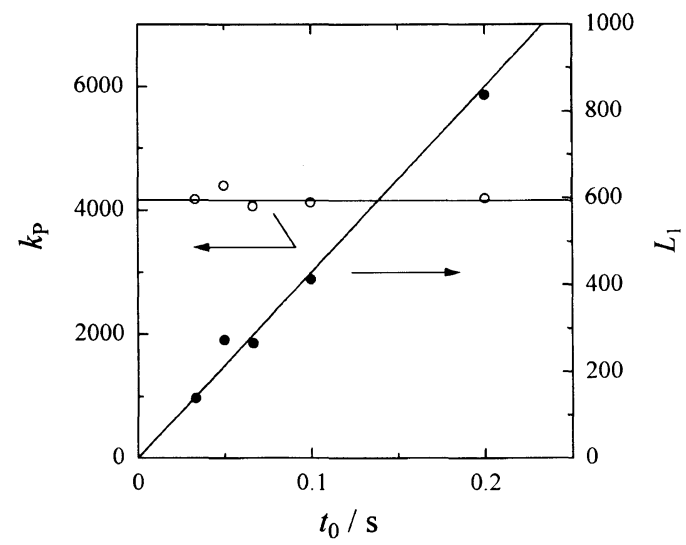

Figure 5. Dependence of $k_{\mathrm{p}}(\bigcirc)$ and $L_{1}(0)$ of the polymer on the time interval of laser pulse in benzene at $30^{\circ} \mathrm{C}$.

experiments were carried out at a $t_{0}$ of 0.1 or $0.2 \mathrm{~s}$. We analyzed the curve in Figure 4 and the results are summarized in Table III. In Figure 5, we plot the data in Table III. Figure 5 clearly shows how the inflection points shift to higher molecular weights as $t_{0}$ increases, but the $k_{\mathrm{p}}$ values are almost constant. The SEC curves in Figure 6 were obtained by changing the concentration of $\mathrm{VCZ}$ from 0.25 to $1.5 \mathrm{~mol} \mathrm{~L}^{-1}$. As the concentration increased, the curves shifted toward a higher molecular weight side and the second peak increased with the decrease of the first peak. The results analyzed from the curves of Figure 6 are summarized in Table IV. $L_{1}$ was proportional to the monomer concentration, but $k_{\mathrm{p}}$ was definite. Thus, this system is adequate for the measurement by the PLP method.

We tested the reliability of our PLP technique, using styrene which has been studied by many researchers. $^{8-10,28}$ We used a repetition rate of $10 \mathrm{~Hz}$ and Irgacure $369\left(2 \times 10^{-3} \mathrm{~mol} \mathrm{~L}^{-1}\right)$ photoinitiator in bulk styrene, in the range of $30-70^{\circ} \mathrm{C}$. Our data are summarized

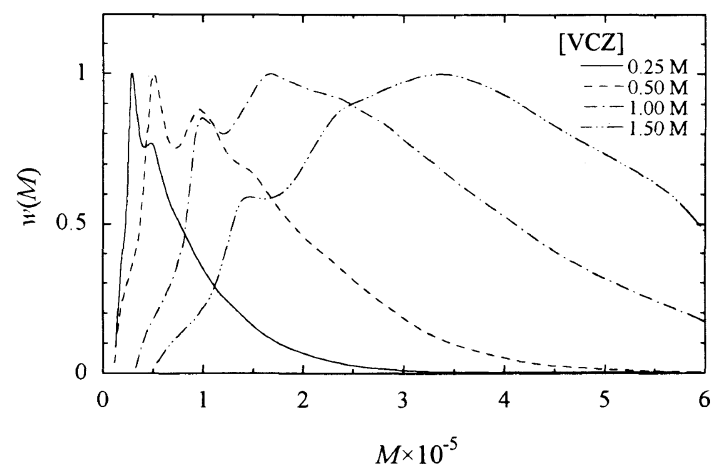

Figure 6. Dependence of molecular weight distribution of the polymer on the VCZ concentration in benzene at $30^{\circ} \mathrm{C}$.

Table IV. Effect of monomer concentration in PLP experiment ${ }^{\mathrm{a}}$

\begin{tabular}{ccccc}
\hline VCZ Concentration/mol L & 0.25 & 0.5 & 1.0 & 1.5 \\
\hline MW at $L_{1}\left(\times 10^{4}\right)$ & 2.02 & 4.24 & 8.29 & 12.1 \\
$L_{1}\left(\times 10^{3} \mathrm{~L} \mathrm{~mol}^{-1} \mathrm{~s}^{-1}\right)$ & 105 & 220 & 429 & 626 \\
$k_{\mathrm{p}}(\times .19$ & 4.39 & 4.29 & 4.17 \\
\hline
\end{tabular}

${ }^{\text {a }}$ Irgacure $369\left(2 \times 10^{-3} \mathrm{~mol} \mathrm{~L}^{-1}\right)$; solvent, benzene; temperature, $30^{\circ} \mathrm{C}$; irradiation wavelength, $351 \mathrm{~nm}$; laser repetition rate, $10 \mathrm{~Hz}$.

Table V. Propagation rate coefficient $k_{\mathrm{p}}$ for styrene evaluated as a function of temperature ${ }^{a}$

\begin{tabular}{ccc}
\hline Temperature $/{ }^{\circ} \mathrm{C}$ & $t_{\mathrm{o}} / \mathrm{s}$ & $k_{\mathrm{p}} / \mathrm{L} \mathrm{mol}^{-1} \mathrm{~s}^{-1}$ \\
\hline 30 & 0.1 & 110 \\
40 & 0.1 & 179 \\
50 & 0.1 & 279 \\
60 & 0.1 & 372 \\
70 & 0.1 & 493 \\
80 & 0.1 & 757
\end{tabular}

${ }^{\text {a }}$ Irgacure $369\left(2 \times 10^{-3} \mathrm{~mol} \mathrm{~L}^{-1}\right)$; irradiation wavelength, $351 \mathrm{~nm}$; laser repetition rate, $10 \mathrm{~Hz}$. Styrene concentration was calculated by using the density eq: $d\left[\mathrm{~g} \mathrm{~cm}^{-3}\right]=0.9236-8.87 \times 10^{-4} T$, where $T$ is the temperature $\left({ }^{\circ} \mathrm{C}\right) .{ }^{28}$

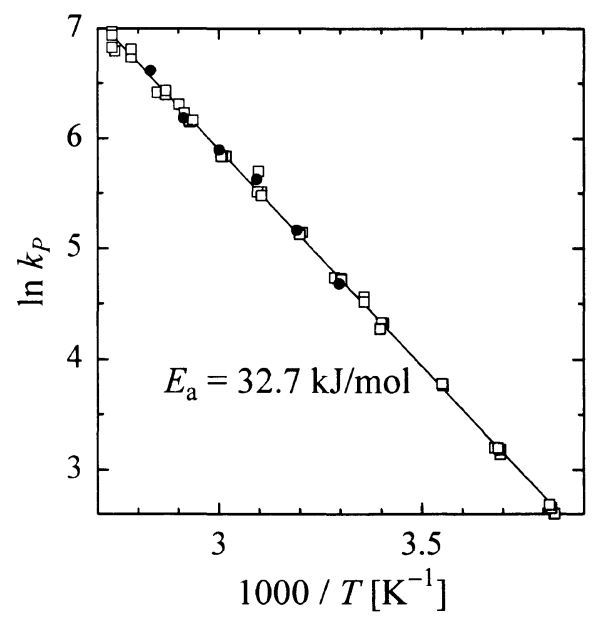

Figure 7. Arrhenius plot for the styrene propagation rate constants determined by PLP. Present work ( $)$ and Manders' result ( $\square$ ).

in Table V. Figure 7 shows our results for styrene and those of Manders et al. ${ }^{28}$ Our results are expressed by eq 4 and are in good agreement with their results,

Polym. J., Vol. 31, No. 10, 1999 
Table VI. Propagation rate coefficient $k_{\mathrm{p}}$ for $\mathrm{VCZ}$ evaluated as a function of temperature ${ }^{a}$

\begin{tabular}{|c|c|c|c|}
\hline Temperature $/{ }^{\circ} \mathrm{C}$ & $t_{0} / \mathrm{s}$ & {$[\mathrm{M}] / \mathrm{mol} \mathrm{L}^{-1}$} & $k_{\mathrm{p}} / \times 10^{3} \mathrm{~mol}^{-1} \mathrm{~s}^{-1}$ \\
\hline \multirow{16}{*}{30} & 0.2 & 0.5 & 4.12 \\
\hline & 0.2 & 0.5 & 4.34 \\
\hline & 0.2 & 0.5 & 4.19 \\
\hline & 0.2 & 1.0 & 4.19 \\
\hline & 0.1 & 1.0 & 4.12 \\
\hline & 0.067 & 1.0 & 4.06 \\
\hline & 0.05 & 1.0 & 4.39 \\
\hline & 0.033 & 1.0 & 4.17 \\
\hline & 0.1 & 0.25 & 4.19 \\
\hline & 0.1 & 0.5 & 4.39 \\
\hline & 0.1 & 1.0 & 4.29 \\
\hline & 0.1 & 1.5 & 4.17 \\
\hline & 0.1 & 1.0 & 4.39 \\
\hline & 0.1 & 1.0 & 4.09 \\
\hline & 0.1 & 1.0 & 4.19 \\
\hline & 0.1 & 1.0 & 4.17 \\
\hline \multirow{4}{*}{40} & 0.2 & 0.5 & 5.39 \\
\hline & 0.2 & 0.5 & 5.63 \\
\hline & 0.2 & 0.5 & 6.05 \\
\hline & 0.2 & 0.5 & 5.53 \\
\hline \multirow{3}{*}{50} & 0.2 & 0.5 & 8.07 \\
\hline & 0.2 & 0.5 & 8.47 \\
\hline & 0.2 & 0.5 & 8.28 \\
\hline \multirow{3}{*}{60} & 0.2 & 0.5 & 10.1 \\
\hline & 0.2 & 0.5 & 10.6 \\
\hline & 0.2 & 0.5 & 10.4 \\
\hline \multirow{3}{*}{70} & 0.2 & 0.5 & 16.7 \\
\hline & 0.2 & 0.5 & 15.4 \\
\hline & 0.2 & 0.5 & 16.1 \\
\hline
\end{tabular}

a VCZ; Irgacure $369\left(2 \times 10^{-3} \mathrm{~mol} \mathrm{~L}^{-1}\right)$; solvent, benzene; irradiation wavelength, $351 \mathrm{~nm}$.

$$
\ln \left(\frac{k_{\mathrm{p}}}{\mathrm{L} \mathrm{mol}^{-1} \mathrm{~s}^{-1}}\right)=\ln \left(10^{7.633}\right)-\frac{32.51 \mathrm{~kJ} \mathrm{~mol}^{-1}}{R T}
$$

Then, we measured the $k_{\mathrm{p}}$ of $\mathrm{VCZ}$ in the temperature range of 30 to $70^{\circ} \mathrm{C}$ as shown in Table VI. Usually the temperature dependence of a rate constant is expressed by the following linearized form of the Arrhenius equation.

$$
\ln k_{\mathrm{p}}=\ln A-\frac{E_{\mathrm{A}}}{R T}
$$

However, it has recently been pointed out ${ }^{9,28-30}$ that from a statistical point of view, the more correct way to obtain values of Arrhenius parameters is to carry out the non-linear fitting of $k_{\mathrm{p}}(T)$ data with the Arrhenius equation itself:

$$
k_{\mathrm{p}}=A \exp \left(\frac{-E_{\mathrm{A}}}{R T}\right)
$$

We used the recommended standard non-linear leastsquares (NLLS) fitting for determination of Arrhenius parameters, and calculated Arrhenius parameters by Herk's method ${ }^{29}$ for the data points in Table VI. This method sequentially searches the entire sum-of-squares of residuals space (SS) for its global minimum.

Figure 8 shows the $95 \%$ joint confidence interval for the Arrhenius parameters with the SS from NLLS fit,

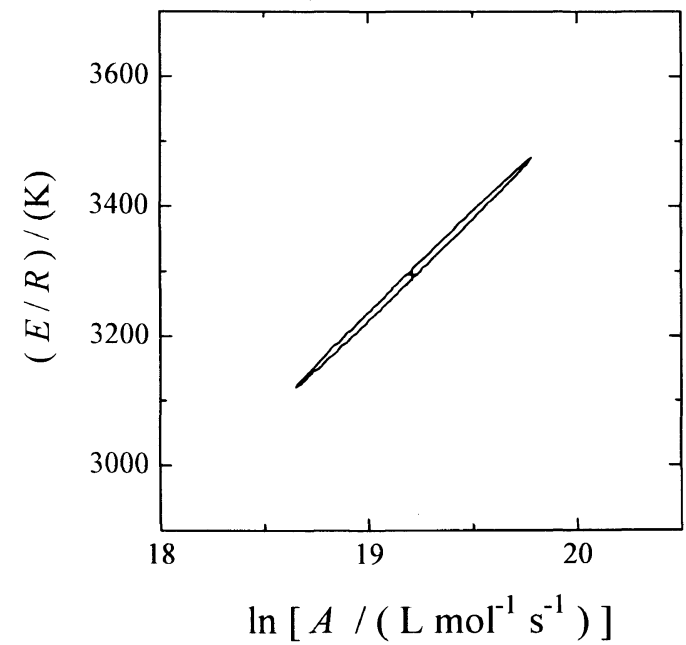

Figure 8. The $95 \%$ joint confidence intervals for Arrhenius parameters $\ln A$ and $E / R$ from non-linear least-squares fitting of $k_{\mathrm{p}}$ data for $N$-vinylcarbazole. Best fit value $(+)$ of $\ln A$ and $E / R$.

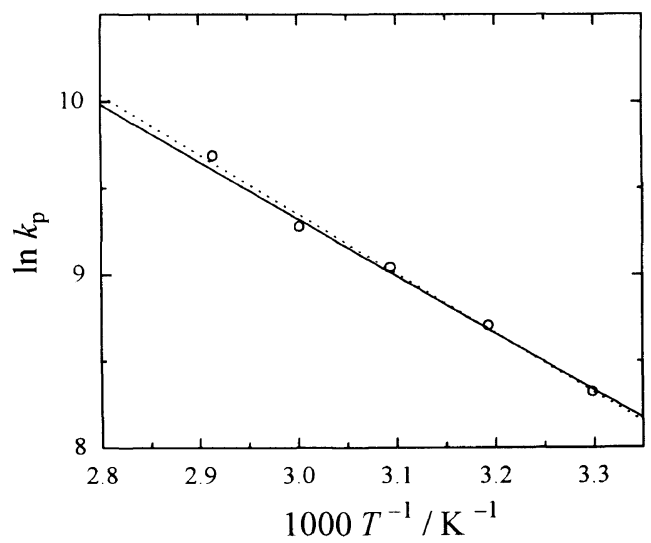

Figure 9. Arrhenius plot for the $N$-vinylcarbazole propagation rate constants determined by PLP. Present work ( $O)$; non-linear least-square fitting, eq $7,(-)$; linear least-square fitting $(\cdots)$.

where the so-called F-distribution was used for joint confidence interval construction. As can be seen from Figure 8, the joint confidence interval was approximately elliptical in shape. The center in this ellipsoid is the best-fit parameter. The values are $A=2.20 \times 10^{8} \mathrm{~L} \mathrm{~mol}^{-1} \mathrm{~s}^{-1}$, $E_{\mathrm{A}}=27.4 \mathrm{~kJ} \mathrm{~mol}^{-1}$, which are given in eq 7 .

$$
k_{\mathrm{p}}=2.20 \times 10^{8} \exp \left(\frac{-27.4 \mathrm{~kJ} \mathrm{~mol}^{-1}}{R T}\right) \quad\left[\mathrm{L} \mathrm{mol}^{-1} \mathrm{~s}^{-1}\right]
$$

The $k_{\mathrm{p}}$ value at $30^{\circ} \mathrm{C}$ calculated from Arrhenius parameters was $4.16 \times 10^{3} \mathrm{~L} \mathrm{~mol}^{-1} \mathrm{~s}^{-1}$. As shown in Figure 9 it is nearly identical to that of the linear fit. The value of activation energy is slightly smaller than that of styrene $\left(32.51 \mathrm{~kJ} \mathrm{~mol}^{-1}\right)^{9}$ and larger than that of methyl methacrylate $\left(22.36 \mathrm{~kJ} \mathrm{~mol}^{-1}\right),{ }^{14}$ but the value of frequency factor is much higher than those of styrene $\left(4.27 \times 10^{7} \mathrm{~L} \mathrm{~mol}^{-1} \mathrm{~s}^{-1}\right)^{9}$ and MMA $\left(2.67 \times 10^{6} \mathrm{~L} \mathrm{~mol}^{-1}\right.$ $\left.\mathrm{s}^{-1}\right) .{ }^{14}$ That is, the large propagation rate constant of $\mathrm{VCZ}$ is mainly due to the large frequency factor. VCZ has a bulkier side group (large mass) than other monomers. Then this may cause the increase in the vibrational and internal rotational partition function which results in the increase in the frequency factor. ${ }^{31-33}$ 
The study on this cause is further in progress.

As for the discrepancy between the previously reported value $^{3}$ and the present one, the following reasons can be considered: (1) the accuracy of the rotating sectordilatometry method was not enough to measure the rate of polymerization, (2) there has been no effective and clear-cut radical photoinitiator for $\mathrm{VCZ}$ monomer. ${ }^{34}$ The present study showed a way to measure the rate constants of radical polymerization in solution.

\section{CONCLUSION}

The propagation rate coefficients of $\mathrm{VCZ}$ were measured by the PLP technique, with an Irgacure 369 photoinitiator in the temperature range of $30-70^{\circ} \mathrm{C}$. They were evaluated by using the non-linear least-squares fitting for determination of Arrhenius parameters. Their values were $A=2.20 \times 10^{8} \mathrm{~L} \mathrm{~mol}^{-1} \mathrm{~s}^{-1}$ and $E_{\mathrm{A}}=27.4$ $\mathrm{kJ} \mathrm{mol}^{-1}$ with the $95 \%$ joint confidence interval. The value $k_{\mathrm{p}}$ in benzene at $30^{\circ} \mathrm{C}$ was $4.16 \times 10^{3} \mathrm{~L} \mathrm{~mol}^{-1} \mathrm{~s}^{-1}$.

\section{REFERENCES}

1. A. Ledwith, Account Chem. Res., 5, 133 (1972).

2. J. M. Pearson and M. Stolka, "Poly ( $N$-vinylcarbazole)," Gordon and Breach Sci. Pub., New York, N.Y., 1981.

3. J. Hughes and A. M. North, Trans. Faraday Soc., 62, 1866 (1966).

4. J. Bandrup and E. H. Immergut, Ed., "Polymer Handbook," 3rd ed, Wiley-Interscience, New York, N.Y., 1989.

5. M. Ohoka, S. Nishimoto, and M. Yamamoto, J. Photopolym. Sci. Tech., 5, 235 (1992).

6. O. F. Olaj, I. Bitai, and F. Hinkelman, Makromol. Chem., 188, 1689 (1987).

7. P. Aleksandrov, V. N. Genkin, M. S. Kitai, I. M. Smirnova, and V. V. Sokolov, Sov. J. Quantum Electron., 7, 547 (1977).

8. R. A. Hutchinson, M. T. Aronson, and J. R. Richards, Macromolecules, 26, 6410 (1993).

9. M. Buback, R. G. Gilbert, R. A. Hutchinson, B. Klumperman, F.-D. Kuchta, B. G. Manders, K. F. O’Driscoll, G. T. Russell, and J. Schweer, Macromol. Chem. Phys., 196, 3267 (1995).

10. M. Buback and F. -D. Kuchta, Macromol. Chem. Phys., 196, 1887(1996).

11. M. Buback and B. Deneger, Makromol, Chem., 194, 2875 (1993).
12. S. Beuermann, D. A. Paquet, Jr., J. H. McMinn, and R. A. Hutchinson, Macromolecules, 29, 4206 (1996).

13. R. A. Lyons, J. Hutovic, M. C. Piton, D. I. Christie, P. A. Clay, B. G. Manders, S. H. Kable, and R. Gilbert, Macromolecules, 29, 1918 (1996)

14. S. Beuermann, M. Buback, T. P. Davis, R. G. Gilbert, R. A Hutchinson, O. F. Olaj, G. T. Russell, J. Schweer, and A. M. van Herk, Macromol. Chem. Phys., 198, 1545 (1997).

15. M. Buback, U. Geers, C. H. Kurz, and J. Heyne, Macromol. Chem. Phys., 198, 3451 (1997).

16. R. A. Hutchinson, S. Beuermann, D. A. Paquet, Jr., J. H. Mcminn, and C. Jackson, Macromolecules, 31, 1542 (1998).

17. M. D. Zammit, M. L. Coote, T. P. Davis, and G. D. Willett, Macromolecules, 31, 955 (1998).

18. R. A. Hutchinson, D. A. Paquet, Jr., J. H. McMinn, and R. E. Fuller, Macromolecules, 28, 4023 (1995).

19. O. F. Olaj, I. Bitai, and G. Zifferer, Eur. Polym. J., 25, 535 (1989)

20. R .A. Hutchinson, J. R. Richards, and M. T. Aronson, Macromolecules, 27, 4530 (1994).

21. S. Beuermann, M. Buback, and G. T. Rusell, Macromol. Chem. Rapid Commun., 15, 647 (1994).

22. S. Beuermann, D. A. Paquet, Jr., J. H. McMinn, and R. A. Hutchinson, Macromolecules, 30, 194 (1997).

23. D. A. Shipp, T. A. Smith, D. H. Solomon, and G. Moad, Macromol. Chem., Rapid Commun., 16, 837 (1995).

24. G. Sitaramaiah and D. Jacobs, Polymer, 11, 165 (1970).

25. M. Sawamoto, J. Fujimori, and T. Higashimura, Macromolecules, 20, 916 (1987).

26. M. L. Coote, M. D. Zammit, and T. P. Davis, Trends Polym. Sci., 6, 189 (1996).

27. V. Desobry, K. Dietliker, R. Hüsler, L. Misev, M. Rembold, G. Rist, and W. Rutsch, in C. E. Hoyle and J. F. Kinstle, Ed., "Radiation Curing of Polymeric Materials," ACS Symposium Series No. 417, American Chemical Society, Washington, D.C., $1990, \mathrm{p} 92$.

28. B. G. Manders, G. Chambard, W. J. Kingma, B. Klumperaman, A. M. van Herk, and A. L. German, J. Polym. Sci., Part A, Polym. Chem., 34, 2473 (1996).

29. A. M. van Herk, J. Chem. Educ., 72, 138 (1995).

30. R. A. Hutchinson, S. Beuermann, D. A. Paquet, Jr., and J. H. McMinn, Macromolecules, 30, 3490 (1997).

31. T. Fueno and T. Kamachi, Macromolecules, 21, 908 (1988).

32. J. P. A. Heuts, R. G. Gilbert, and L. Radom, Macromolecules, 28, 8771 (1995)

33. J. P. A. Heuts, Sudarko, and R. G. Gilbert, Macromol. Symp., 111, 147 (1996)

34. J. C. Bevington and C. J. Dyball, J. Chem. Soc., Faraday Trans. I, 71, 2226 (1975) 